\title{
Quantification of phenolic compounds by capillary zone electrophoresis in extracts of four commercial types of mate herb before and after acid hydrolysis
}

\author{
Carolina Schaper Bizzotto a , Adriana Dillenburg Meinhart a , Ana Cecília Poloni Rybka b, \\ Merenice Roberto Sobrinho ${ }^{a}$, Stanislau Bogusz Junior ${ }^{a}$, Cristiano Augusto Ballus ${ }^{a}$, Helena Teixeira Godoy ${ }^{\text {a,* }}$ \\ a Department of Food Science, Faculty of Food Engineering, University of Campinas (UNICAMP), 13083-862, Campinas, SP, Brazil \\ b Embrapa Semiárido, 56302-970, Petrolina, PE, Brazil
}

\section{A R T I C L E I N F O}

\section{Article history:}

Received 8 May 2012

Accepted 16 June 2012

Available online 28 June 2012

\section{Keywords:}

Mate herb

Rutin

Caffeic acid

3,4-Dihydroxybenzoic acid

Optimization

Hydrolysis

\begin{abstract}
A B S T R A C T
Mate herb, Ilex paraguariensis St. Hil., is a plant cultivated in South America. Studies have evidenced the presence of phenolic compounds in mate herb, however, there are no reports on the contents of these compounds in different types of mate herb sold in the South Region of Brazil. In this study, capillary zone electrophoresis was used to quantify phenolic compounds in three lots of each of four types of commercial mate herb (traditional, native, large ground, and suave). Analysis was performed before and after acid hydrolysis. Hydrolysis time, temperature and chloridric acid concentration were optimized by central composite design to maximize the amounts of free phenolic compounds obtained after hydrolysis. Before hydrolysis, high amounts of rutin were detected, while after hydrolysis, high amounts of caffeic acid and 3,4-dihydroxybenzoic acid were obtained, giving evidence that mate herb should be further investigated as a major source of these compounds.
\end{abstract}

(C) 2012 Elsevier Ltd. All rights reserved.

\section{Introduction}

Mate herb, Ilex paraguariensis St. Hil., is a native plant of South America (Kussler, Sabedot, Garcia, \& Peronti, 2004). The leaves and branches are used in the preparation of teas (known as mate tea), partial infusion drinks with hot water (chimarrão), and a total infusion cold drink (tererê) (Filip, Lotito, Ferraro, \& Fraga, 2000). According to Ibge, the Brazilian Geography and Statistics Institute, the tea prepared from the leaves of I. paraguariensis is the most consumed tea in Brazil (Ibge (Instituto Brasileiro de Geografia e Estatística - Brazilian Geography and Statistics Institute), 2012). In South America, about 30\% of the population consumes more than $1 \mathrm{~L}$ of chimarrão and/or tererê per day (Filip et al., 2000). The per capita consumption of mate herb in Brazil is estimated at $1.2 \mathrm{~kg}$ per year, while in Argentina and Uruguay, it ranges from 5 to $7 \mathrm{~kg}$. Products based on mate herb are also exported to the United States and European countries (Heck \& Mejia, 2007).

The most common commercial mate herb is called "traditional". It is the most consumed and it is made up of a mixture of leaves and branches of mate herb from both native and cultivated plants, generally in the proportion of 50\%/50\%; "native" mate herb, constituted of only native mate herb or with little addition of cultivated mate herb, being characterized by a sharp taste; "suave" mate herb, which is a blend of native and cultivated mate herb, with added saccharose; and "large ground" mate herb, made up of a mixture of

\footnotetext{
* Corresponding author. Tel.: +55 193521 4024; fax: +55 1935212153

E-mail address: helena@fea.unicamp.br (H.T. Godoy).
}

native and cultivated plants, but with a larger ground particle size. It is characterized by better permeability to hot water among the mate herb particles (Meinhart, Bizzotto, Ballus, Prado, et al., 2010; Meinhart, Bizzotto, Ballus, Rybka, et al., 2010) and by a pronounced bitter taste. The Brazilian laws do not regulate the composition proportions of native and cultivated mate herb, the amount of saccharose added (to suave mate) or the particle size after grinding. These parameters are determined by the processing companies based on sensorial acceptance parameters.

Mate herb has been more and more acknowledged by the scientific community as a vegetable species with high levels of phenolic compounds, including galic acid, caffeic acid, syringic acid, ferrulic acid, and $p$-cumaric acid, as well as flavonoids rutin, quercetin, and kaempferol (Bastos, Fornari, Queiroz, \& Torres, 2006; Bixby, Spieler, Menini, \& Gugliucci, 2005; Bravo, Goya, \& Lecumberri, 2007; Cardozo et al., 2007; Carini, Facino, Aldini, \& Colombo, 1998; Clifford, 1999; Filip, Lopez, Giberti, Coussio, \& Ferraro, 2001; Filip et al., 2000; Fuhrman \& Aviram, 2002; Vieira et al., 2008). These compounds are considered reducing agents, which protect the body tissue against oxidative stress events. Oxidative stress events contribute to cell aging and various degenerative diseases, such as cancer, cardiovascular diseases, inflammations and others (Scalbert, Manach, Morand, Rémésy, \& Jiménez, 2005).

The prevention of non-transmissible chronic diseases is a matter of great interest for scientists, consumers, and for the food industry. Mosimann, Wilhelm-Filho, and Silva (2006) observed the reduction of the cholesterol level and the size of lesions in the aorta of rabbits fed on a diet containing mate herb. Studies in healthy dyslipidemic 
human beings who ingested beverages based on I. paraguariensis for two months presented an improvement in the serum lipid parameters and the LDL cholesterol was significantly reduced simultaneously to the increase in the HDL (De Morais et al., 2009). Other studies with beverages made from mate herb have confirmed their beneficial effects for health, with hepatoprotection, choleretic, diuretic, and hypocholesterolemic effects, besides effects in individuals with rheumatism, thrombosis and obesity (Athayde, Coelho, \& Schenkel, 2000; Filip et al., 2000, 2001; Gugliucci \& Menini, 2002). Some authors even discuss the possibility of also considering mate herb a functional food (Zuin, Montero, Bauer, \& Popp, 2005).

Most methods of extraction of phenolic compounds employ methanol or methanol:water as solvents. Phenolic acids are rarely found in free form in plants. They usually occur as esters or glycosides that can be released by acid or alkaline hydrolysis. In the family of the hydroxycinnamic acids, caffeic acid is the major compound, occurring in the plants mainly as an ester, such as caffeoylquinic acids (Rivelli, Almeida, Ropke, \& Barros, 2011).

The phenolic compounds are separated mostly by using highperformance liquid chromatography and capillary electrophoresis. Both separation techniques are largely employed due to the use of mild temperatures of analysis, which prevents the degradation of the phenolic compounds. In liquid chromatography, the phenolic compounds are generally separated in reverse phase systems (Berté, Beux, Spada, Salvador, \& Hoffmann-Ribani, 2011; Dutra, Hoffmann-Ribani, \& Ribani, 2010; Murakami et al., 2011; Pagliosa et al., 2010; Zuin et al., 2005). In capillary electrophoresis, the most common is the separation of these substances by capillary zone electrophoresis (Ballus, Meinhart, Bruns, \& Godoy, 2011; Ballus, Meinhart, Oliveira, \& Godoy, 2012; Heller, Vitali, Oliveira, Costa, \& Micke, 2011; Lee, Boyce, \& Breadmore, 2011; Pomilio, Trajtemberg, \& Vitale, 2001).

Capillary electrophoresis has gained more and more attention due to its high efficiency of separation, low reagent cost, as the electrolyte is made up only of salts, short analysis time, and low production of residues (Ballus et al., 2011; Heller et al., 2011; Honegr, Šafra, Polašek, \& Pospíšilová, 2010; Meinhart, Ballus, Bruns, Lima Pallone, \& Godoy, 2011; Meinhart, Bizzotto, Ballus, Prado, et al., 2010; Meinhart, Bizzotto, Ballus, Rybka, et al., 2010). However, it is still little applied in the analysis of phenolic compounds of mate herb.

The objective of this study was to separate, identify, and quantify the phenolic compounds present in the extracts of four commercial types of mate herb (I. paraguariensis) before and after hydrolysis by capillary zone electrophoresis with a diode array detector. The analysis method was adapted and validated and the hydrolysis process was optimized by central composite design for obtaining the greatest concentration of phenolic compounds in the hydrolyzed mate herb extract.

\section{Materials and methods}

\subsection{Standards and reagents}

Standards of rutin, quercetin, kaempferol, caffeic acid, $p$-cumaric acid, ferrulic acid, galic acid, and 3,4-dihydroxybenzoic acid were obtained from Sigma-Aldrich (USA). Chromatography-grade methanol was purchased from J.T. Baker (USA), methanol P.A., from Synth (Brazil), boric acid, from Ecibra (Brazil), $\mathrm{NaOH}$, from Nuclear (Brazil), and $\mathrm{HCl}$, from Synth (Brazil).

Stock solutions in chromatography-grade methanol were prepared for the quantification of the phenolic compounds and stored at $-18{ }^{\circ} \mathrm{C}$ in the dark. Working solutions were prepared in methanol: water (30:70) with concentrations ranging from 0.5 to $75 \mathrm{mg} \mathrm{L}^{-1}$. Milli-Q purified (Millipore Corporation, France) water with resistivity of $18.2 \mathrm{M} \Omega \mathrm{cm}^{-1}$ was used in the experiments. All solutions were filtered with membrane filters (Millipore Corporation, France) with a porosity of $0.45 \mu \mathrm{m}$ and sonicated for $5 \mathrm{~min}$ before injection.

\subsection{Samples}

Four types of mate herb (traditional, native, large ground, and suave) sold in the state of Rio Grande do Sul, Brazil by Ervateira Vier (Rio Grande do Sul, Brazil) were analyzed in three separate lots. The mate herb types analyzed differed in terms of leaf and twig (branch) contents and sugar contents, as shown in Table 1. The particle size of the traditional, native and suave mate herb was approximately 200 mesh after grinding, and the large ground particle size about 500 mesh.

\subsection{Extraction of phenolic compounds of mate herb samples}

The samples were submitted to the extraction of the phenolic compounds as described by Scherer and Godoy (2009). Approximately $500 \mathrm{~g}$ of mate herb were ground in a Marconi TE 600 grinder (São Paulo, Brazil) and sieved with a 100 mesh sieve. Next, $100 \mathrm{~mL}$ of methanol P.A. were added to $20 \mathrm{mg}$ of ground sample in an Erlenmeyer and the mixture was agitated for $3 \mathrm{~h}$. The extract was filtered and the solid residue was agitated again with another $100 \mathrm{~mL}$ of methanol for $1 \mathrm{~h}$ and filtered. The two methanolic extracts were pooled and evaporated to dryness in a rotary evaporator at $38{ }^{\circ} \mathrm{C}$ in the dark, and the dried extract was stored at $-18{ }^{\circ} \mathrm{C}$ until use. The dry extracts were submitted to the analysis of phenolic compounds, before and after acid hydrolysis, under the currently optimized conditions. All determinations were carried out in triplicate.

\subsection{Adaptation and validation of the capillary zone electrophoresis method}

Phenolic compounds were separated and quantified in an Agilent G1600AX capillary electrophoresis apparatus (Agilent Technologies, Germany) fitted with a diode array detector (UV-vis), automatic injector, and the temperature control system adjusted for $25^{\circ} \mathrm{C}$.

On the first day of use, the capillary was activated and conditioned by washing with a $1 \mathrm{~mol} \mathrm{~L}^{-1} \mathrm{NaOH}$ solution at $1000 \mathrm{mbar}$ for $30 \mathrm{~min}$, followed by $10 \mathrm{~min}$ with water and $10 \mathrm{~min}$ with run electrolyte. At the beginning of each day, the capillary was conditioned for 5 min with $1 \mathrm{~mol} \mathrm{~L}^{-1} \mathrm{NaOH}$ solution, followed by 5 min with water and $10 \mathrm{~min}$ with electrolyte. At the end of the day, the capillary was cleaned for 5 min with $1 \mathrm{~mol} \mathrm{~L}^{-1} \mathrm{NaOH}$ solution, followed by water for $5 \mathrm{~min}$. Conditioning between runs was performed by washing the capillary for $1 \mathrm{~min}$ with $1 \mathrm{~mol} \mathrm{~L}^{-1} \mathrm{NaOH}$ solution, resting for $0.5 \mathrm{~min}$, and washing with water for $1 \mathrm{~min}$, with electrolyte for $1 \mathrm{~min}, 0.5 \mathrm{~min}$ rest, and again with electrolyte for $1 \mathrm{~min}$. The run electrolytes were replaced at every 15 runs. All these parameters were fundamental to ensure the repeatability of the analytical method.

The analysis method was adapted from the method developed by Ballus et al. (2012) for the assessment of phenolic compounds in wine samples by capillary zone electrophoresis and was validated in relation to the parameter intra-run precision (quantification of the same sample 10 consecutive times), inter-run precision (quantification of the samples on 5 different days), linearity (from 0.5 to $75 \mathrm{mg} \mathrm{L}^{-1}$ ) and precision in the linear range of work, limits of detection and quantification (calculated as three and six times the signal/ noise ratio, respectively) pursuant to the recommendations of the Brazilian Agency of Sanitary Surveillance (Anvisa (Agência Nacional de Vigilância Sanitária - Brazilian Agency of Sanitary Surveillance),

Table 1

Composition of mate herbs used in the experiments.

\begin{tabular}{lllll}
\hline Composition & "Suave" & "Traditional" & "Native" & "Large ground" \\
\hline Leaves of native plants & $25 \%$ & $39 \%$ & $60 \%$ & $41 \%$ \\
Leaves of cultivated plants & $50 \%$ & $53.5 \%$ & $22.5 \%$ & $46 \%$ \\
Branches & $15 \%$ & $7.5 \%$ & $17.5 \%$ & $13 \%$ \\
Sugar & $10 \%$ & - & - & - \\
\hline
\end{tabular}


2012), only for the three compounds detected in the matrix (rutin, caffeic acid, and 3,4-dihydroxybenzoic acid).

\subsection{Optimization of the acid hydrolysis}

To evaluate the effect of acid hydrolysis on the contents of the phenolic compounds in the mate herb extracts, the hydrolysis process was optimized with a $2^{3}$ central composite design with central and axial points. The effects of temperature (from 31 to $99{ }^{\circ} \mathrm{C}$ ), of the heating time (from 19 to $221 \mathrm{~min}$ ), and of the concentration of $\mathrm{HCl}$ (from 0.96 to $11 \mathrm{~mol} \mathrm{~L}^{-1}$ ) were evaluated. These values correspond to the codified levels from -1.68 to +1.68 . The tests were performed using $300 \mathrm{mg}$ of dry extract of "traditional" mate herb and heating under reflux. Concentrations of rutin, caffeic acid, and 3,4-dihydroxybenzoic acid, obtained by the capillary zone electrophoresis coupled to diode array detector method, were used as responses. Tests were performed in random order and, at the central point, four replicates were randomly executed to evaluate the experimental error. The models were validated by mean of the analysis of variance (ANOVA) at the 95\% confidence level. Data were analyzed using Statistica 6.0 (Statsoft, USA) software.

\subsection{Quantification of the phenolic compounds before and after acid hydrolysis}

The phenolic compounds present in the extracts were analyzed before and after hydrolysis. For the analysis before hydrolysis, the dry extracts were solubilized in 30:70 methanol:water, giving a final concentration of $6 \mathrm{mg} \mathrm{mL}^{-1}$. The solubilized extracts were filtered with membranes, pore size $0.45 \mu \mathrm{m}$, sonicated for $5 \mathrm{~min}$, and injected into the capillary electrophoresis equipment. In the analysis after hydrolysis, $300 \mathrm{mg}$ of dry extract was submitted to the optimized hydrolysis conditions and neutralized with $40 \% \mathrm{NaOH}$ and adjusted to a volume of $100 \mathrm{~mL}$. Next, the hydrolyzed and neutralized extract was filtered, sonicated, and injected into the capillary electrophoresis system in the same analytical conditions as used for the non-hydrolyzed extracts.

\subsection{Statistical analysis}

In order to verify the assumption of variance homoscedasticity of the phenolic compound content in the samples analyzed, the Cochran's test (95\% confidence level) was applied. Also, the means were compared using ANOVA and Tukey test, both at 95\% confidence level. All these analysis were done using the software Statistica 6.0 (Statsoft, USA).

\section{Results and discussion}

\subsection{Adaptation and validation of the separation method}

When test extracts of mate herb samples, before and after hydrolysis, were analyzed by the original method of Ballus et al. (2012), good selectivity and smaller matrix complexity were obtained in relation to the wine samples reported, which enabled the adaptation of some parameters to reduce the run time without compromising the separation. Among the eight compounds of interest, only rutin, caffeic acid, and 3,4-dihydroxybenzoic acid were reliably identified in the extracts before and after hydrolysis. Thus, it was possible to reduce the effective length of the capillary from 60 to $40 \mathrm{~cm}$ and modify the concentration of the electrolyte from 175 to $100 \mathrm{mmol} \mathrm{L}^{-1}$, maintaining the $\mathrm{pH}$ at 9.0 , the voltage at $30 \mathrm{kV}$, and the detection at $217 \mathrm{~nm}$. The separation efficiency was maintained after these alterations and the run time was reduced from 19 min of the original method to only $4 \mathrm{~min}$.

In this approach, the online pre-concentration was important to improve the limits of detection. In the original method applied to wines, the injection was performed at 50 mbar for $30 \mathrm{~s}$, followed by voltage reversion to $-20 \mathrm{kV}$ for $5 \mathrm{~s}$. This was sufficient to narrow the sample band and improve the limits of detection by up to twenty-fold. Due to the different characteristics of the mate herb extract in relation to the wines, mainly in relation to the proportion and the type of organic solvent (10\% ethanol for wines and 30\% methanol for the mate herb), and due to the other modifications of the method made, it was necessary to adjust the time of application of the reverse voltage to $10 \mathrm{~s}$, while maintaining the other parameters.

The adapted method was validated and shown to be adequate for the analysis with the parameters and limits set by Anvisa (Agência Nacional de Vigilância Sanitária - Brazilian Agency of Sanitary Surveillance) (2012). The intra-run precision $(n=10)$ coefficients ranged from 0.95 to $1.90 \%$ for the peak area. The coefficient of variation of the inter-run precision (evaluated in five different days) ranged from 1.49 to $2.56 \%$. The method linearity was adequate in the range of $0.5-75 \mathrm{mg} \mathrm{L}^{-1}$, with a determination coefficient $\left(\mathrm{r}^{2}\right)$ of 0.9982 for rutin, 0.9995 for caffeic acid, and 0.9994 for 3,4-dihydroxybenzoic acid. The coefficients of variation at the point of the linear range of work were lower than $3.2 \%$, except for the point of the greatest dilution, the coefficient of variation of which was $5.7 \%$ maximum. The limits of detection were $0.14 \mathrm{mg} \mathrm{L}^{-1}$ for rutin, $0.05 \mathrm{mg} \mathrm{L}^{-1}$ for caffeic and 3,4dihydroxybenzoid acids. The limits of quantification were $0.28 \mathrm{mg} \mathrm{L}^{-1}$ for rutin, $0.10 \mathrm{mg} \mathrm{L}^{-1}$ for caffeic and 3,4-dihydroxybenzoid acids.

\subsection{Optimization of the hydrolysis process}

The migration times of some intense analytical signals in the preliminary tests of the mate herb extracts did not correspond to any of the investigated standards. Co-chromatography indicated that they did not actually correspond to the compounds under investigation. However, the absorption spectra were very similar to those of the standards of caffeic acid and 3,4-dihydroxybenzoic acid. Considering that in studies by Filip et al. (2001), Bixby et al. (2005), Bastos et al. (2006), Bravo et al. (2007), Cardozo et al. (2007), and Vieira et al. (2008), glycosylated phenolic compounds had been identified in mate herb samples, we investigated the hypothesis that these signals might correspond to the different forms of glycosylated phenolic compounds. To confirm this hypothesis, mild acid hydrolysis under heating was performed based on the studies of Huber, Hoffmann-Ribani, and Rodriguez-Amaya (2009). In this preliminary test, there was a partial reduction of the three analytical signals and a slight increase in the signal of caffeic acid. To investigate the optimal condition of analysis, a multivariate optimization of the process was performed.

Table 2 shows the variables (temperature, $\mathrm{HCl}$ concentration, and hydrolysis time) and the levels studied, as well as the responses obtained in each test (concentrations of rutin, caffeic acid, 3,4-dihydroxybenzoic acid). Based on the central composite design results, mathematical models were constructed to predict the optimal conditions of extraction.

These models were initially submitted to the analysis of variance to assess their fitting and presented significant regression (caffeic acid: $\mathrm{MS}_{\mathrm{R}} / \mathrm{MS}_{\mathrm{r}}=3.46$; 3,4-dihydroxybenzoic acid: $\mathrm{MS}_{\mathrm{R}} / \mathrm{MS}_{\mathrm{r}}=4.33$, for a critic $F_{9,8,95 \%}=3.39$ ). However, the analysis of variance showed a significant lack of fitting for both models (caffeic acid: $\mathrm{MS}_{\mathrm{lof}} / \mathrm{MS}_{\mathrm{pe}}=97.8$; 3,4dihydroxybenzoic acid: $\mathrm{MS}_{\mathrm{lof}} / \mathrm{MS}_{\mathrm{pe}}=39683.3$, for a critic $F_{5,3,95 \%}=$ 9.01), which made it unfeasible for their use in predicting the optimal conditions of hydrolysis. In response, the experimental results were analyzed. Rutin was not detected in any of the experimental conditions investigated. This may be explained by the study carried out by Buchner, Krumbein, Rohn, and Kroh (2006), which demonstrated that rutin degrades when heated to $100{ }^{\circ} \mathrm{C}$ in aqueous medium with varying velocity depending on the medium $\mathrm{pH}$.

For caffeic acid content, with only an increase in the concentration of $\mathrm{HCl}$, there was an increase (runs 1 and 2, 3 and 4, 5 and 6, and 16-18). The increase in the hydrolysis time also led to an increase in the concentration (runs 1 and 3, 2 and 4, 5 and 7, and 13-15). The same effect was observed for the temperature (runs 1 and 5, 2 
Table 2

Variables, decodified levels and responses obtained in the multivariate optimization using central composite design.

\begin{tabular}{|c|c|c|c|c|c|c|}
\hline \multirow[t]{2}{*}{ Experiment } & \multicolumn{3}{|c|}{ Decodified levels } & \multicolumn{3}{|c|}{$\begin{array}{l}\text { Responses } \\
\text { ( } \mathrm{mg} 100 \mathrm{~g}^{-1} \text { mate herb) }\end{array}$} \\
\hline & $\begin{array}{l}\text { Temperature } \\
\left({ }^{\circ} \mathrm{C}\right)\end{array}$ & $\begin{array}{l}\text { Time } \\
\text { (min) }\end{array}$ & $\begin{array}{l}\mathrm{HCl} \\
\left(\mathrm{mol} \mathrm{L}^{-1}\right)\end{array}$ & Rutin & $\begin{array}{l}\text { Caffeic } \\
\text { acid }\end{array}$ & $\begin{array}{l}\text { 3,4- } \\
\text { Dihydroxybenzoic } \\
\text { acid }\end{array}$ \\
\hline 1 & 45 & 60 & 3 & nd & 59.5 & 6.4 \\
\hline 2 & 45 & 60 & 9 & nd & 353.5 & 0.7 \\
\hline 3 & 45 & 180 & 3 & nd & 111.8 & nd \\
\hline 4 & 45 & 180 & 9 & nd & 430.5 & 9.3 \\
\hline 5 & 85 & 60 & 3 & nd & 210.2 & 1.7 \\
\hline 6 & 85 & 60 & 9 & nd & 593.7 & 21.0 \\
\hline 7 & 85 & 180 & 3 & nd & 541.1 & 2.8 \\
\hline 8 & 85 & 180 & 9 & nd & 360.7 & 33.8 \\
\hline 9 & 31 & 120 & 6 & nd & 83.4 & 0.5 \\
\hline 10 & 99 & 120 & 6 & nd & 260.2 & 2.5 \\
\hline 11 & 65 & 19 & 6 & nd & 155.9 & 10.8 \\
\hline 12 & 65 & 221 & 6 & nd & 402.0 & 3.6 \\
\hline 13 & 65 & 120 & 0.96 & nd & 55.3 & 0.4 \\
\hline 14 & 65 & 120 & 11.04 & nd & 467.0 & 11.1 \\
\hline 15 & 65 & 120 & 6 & nd & 321.3 & 1.1 \\
\hline 16 & 65 & 120 & 6 & nd & 349.4 & 1.1 \\
\hline 17 & 65 & 120 & 6 & nd & 334.3 & 1.2 \\
\hline 18 & 65 & 120 & 6 & nd & 349.4 & 1.2 \\
\hline
\end{tabular}

nd: not detected.

and 6, 3 and 7). However, the simultaneous increase in the variables $\mathrm{HCl}$, temperature, and hydrolysis time led to a reduction in the concentration (runs 7 and 8, 6 and 8, and 4 and 8). In this way, to reduce the hydrolysis time and obtain the most free forms of caffeic acid, the variable time was reduced to level -1 . Thus, the best hydrolysis condition involved heating for $60 \mathrm{~min}$, reflux at $85{ }^{\circ} \mathrm{C}$ in the presence of $9 \mathrm{~mol} \mathrm{~L}^{-1} \mathrm{HCl}$, followed by neutralization.

To the 3,4-dihydroxybenzonc acid the responses were inconsistent, which made the definition of a standard hydrolysis behavior impossible. As the concentrations of this compound were much lower than those of caffeic acid, the conditions that favored greater yields of caffeic acid were preferred.

Next, the repeatability of the best hydrolysis conditions was evaluated. A variation coefficient of $6.2 \%$ was obtained for the concentration of caffeic acid and of $1.9 \%$ for 3,4-dihydroxybenzoic acid $(n=3)$.

Fig. 1 gives the electropherograms of a sample of traditional mate herb before hydrolysis (1A) and after hydrolysis (1B). Before hydrolysis, the presence of rutin and small amounts of caffeic acid were observed, while 3,4-dihydroxybenzoic acid was not observed. Between the migration times of 2.1 and $2.6 \mathrm{~min}$, three analytical signals $\left(\mathrm{X}_{1}, \mathrm{X}_{2}\right.$ and $\left.\mathrm{X}_{3}\right)$ were observed to have an absorption spectrum that was very similar to those of the standards of caffeic acid and 3,4-dihydroxybenzoic acid. After the optimization of the hydrolysis, these three signals decreased by one hundred-fold, while the levels of caffeic acid and of 3,4-dihydroxybenzoic acid increased significantly.

\subsection{Quantification of rutin, caffeic acid and of 3,4-dihydroxybenzoic} before and after hydrolysis

The results of the analysis of the extracts before and after hydrolysis are given in Table 3. Before hydrolysis, the rutin content was between 343.55 and $516.74 \mathrm{mg} 100 \mathrm{~g}^{-1}$, and that of free caffeic acid was 3.77 and $7.58 \mathrm{mg} 100 \mathrm{~g}^{-1}$ of sample. The levels of 3,4-dihydroxybenzoic acid were below the limits of detection. After hydrolysis, the ranges of 3,4-dihydroxybenzoic acid and of caffeic acid in mate herb were 22.61-35.59 $\mathrm{mg}$ and 443.14-737.49 $\mathrm{mg} 100 \mathrm{~g}^{-1}$, respectively. Considering the Cochran's test (95\%), data variance was homoscedastic $\left(C_{c a l}=0.730\right.$ for rutin concentration before hydrolysis, 0.522 for caffeic acid concentration before hydrolysis, 0.483 for caffeic acid concentration after hydrolysis and 0.410 for 3,4-dihydroxybenzoic acid after hydrolysis,
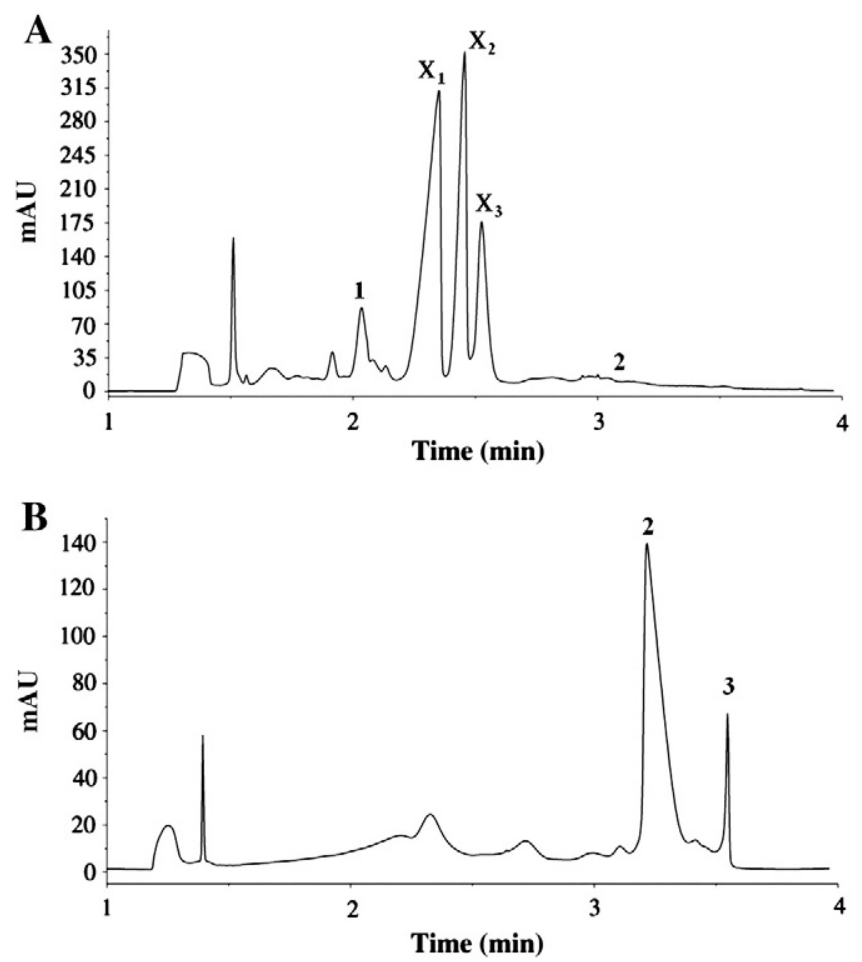

Fig. 1. Electropherogram of the analysis of phenolic compounds in non-hydrolyzed traditional mate herb extracts $(1 \mathrm{~A})$ and acid hydrolyzed in optimal condition (1B). Capillary of $50 \mu \mathrm{m}$ internal diameter and $40 \mathrm{~cm}$ effective length, electrolyte $100 \mathrm{mmol} \mathrm{L}^{-1}$ of boric acid, $\mathrm{pH}=9.0,25^{\circ} \mathrm{C}, 30 \mathrm{kV}$, detection at $217 \mathrm{~nm}$, injection at $50 \mathrm{mbar}$ for $30 \mathrm{~s}$ with reverse voltage of $-20 \mathrm{kV}$ for $10 \mathrm{~s}$. Peak identification: 1, rutin; 2,caffeic acid; 3 , 3,4-dihydroxybenzoic acid; $\mathrm{X}_{1}$, compound with spectrum similar to the caffeic acid; $\mathrm{X}_{2}$, compound with spectrum similar to the caffeic acid; and $X_{3}$, compound with spectrum similar to the caffeic acid.

considering a $\left.C_{\text {crit }}=0.768\right)$. The phenolic compounds content were similar for the different types of mate herb evaluated in this study by ANOVA and Tukey test, at 95\% confidence level.

In contrast, the literature data show a great difference in the contents of these phenolic compounds in samples of I. paraguariensis. Dartora et al.

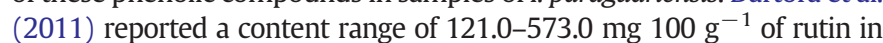
non-hydrolyzed mate herb samples. In non-hydrolyzed leaf extract of I. paraguariensis, Filip et al. (2001) found $23 \mathrm{mg} 100 \mathrm{~g}^{-1}$ of caffeic acid and $60 \mathrm{mg} 100 \mathrm{~g}^{-1}$ of rutin, while Borré et al. (2010) reported contents

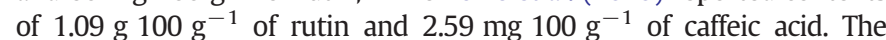
present results agree with all these, despite the different extraction, separation and quantification methods.

It is important to mention that this is the first study by capillary zone electrophoresis in which the contents of these phenolic compounds have been assessed in products commercially available in Brazil and considering the different types of mate herb usually consumed by the population, particularly in South Brazil. The results indicate that these different types of mate herb can be considered matrixes with a high potential for obtaining extracts rich in phenolic compounds. Depending on the objective, extracts with high contents of rutin (without acid hydrolysis) or with high contents of caffeic acid (with hydrolysis) can be obtained.

\section{Conclusions}

The method of capillary zone electrophoresis for the analysis of phenolic compounds adapted and validated in this study had a high efficiency, a low cost for reagents, low production of residues and it was fast. All the validation parameters evaluated performed within the limits set forth by the Brazilian Agency of Sanitary Surveillance. The multivariate optimization was fundamental as, with only 18 experiments, it was 
Table 3

Content of phenolic compounds extracted from mate herbs ( $m g 100 \mathrm{~g}^{-1}$ ).

\begin{tabular}{|c|c|c|c|c|}
\hline Sample & Batch & Rutin & Caffeic acid & 3,4-Dihydroxybenzoic acid \\
\hline & \multicolumn{4}{|c|}{ Before hydrolysis (mean \pm standard deviation, $n=3$ ) } \\
\hline Traditional & A & $495.14 \pm 26.5$ & $4.34 \pm 0.3$ & nd \\
\hline Traditional & B & $480.18 \pm 8.8$ & $5.83 \pm 0.3$ & nd \\
\hline Traditional & $\mathrm{C}$ & $450.84 \pm 11.4$ & $6.01 \pm 0.3$ & nd \\
\hline Large ground & A & $448.04 \pm 9.8$ & $5.17 \pm 0.3$ & nd \\
\hline Large ground & B & $416.67 \pm 22.2$ & $5.81 \pm 0.5$ & nd \\
\hline Large ground & $\mathrm{C}$ & $467.30 \pm 14.1$ & $7.58 \pm 0.2$ & nd \\
\hline Suave & A & $343.55 \pm 13.7$ & $3.77 \pm 0.1$ & nd \\
\hline Suave & $\mathrm{B}$ & $471.78 \pm 15.9$ & $6.34 \pm 0.2$ & nd \\
\hline Suave & $\mathrm{C}$ & $516.74 \pm 7.0$ & $7.21 \pm 0.4$ & nd \\
\hline Native & A & $452.09 \pm 10.1$ & $4.88 \pm 0.3$ & nd \\
\hline Native & B & $515.28 \pm 5.6$ & $6.30 \pm 0.3$ & nd \\
\hline Native & $\mathrm{C}$ & $434.00 \pm 8.2$ & $5.87 \pm 0.2$ & nd \\
\hline \multicolumn{5}{|c|}{ After hydrolysis (mean \pm standard deviation, $n=3$ ) } \\
\hline Traditional & A & nd & $643.74 \pm 101.1$ & $35.59 \pm 8.2$ \\
\hline Traditional & B & nd & $635.34 \pm 87.3$ & $23.94 \pm 1.6$ \\
\hline Traditional & $\mathrm{C}$ & nd & $591.75 \pm 128.8$ & $27.09 \pm 2.2$ \\
\hline Large ground & A & nd & $518.69 \pm 83.1$ & $31.56 \pm 2.7$ \\
\hline Large ground & B & nd & $468.50 \pm 20.3$ & $31.55 \pm 1.2$ \\
\hline Large ground & $\mathrm{C}$ & nd & $564.83 \pm 92.2$ & $31.07 \pm 2.4$ \\
\hline Suave & A & nd & $524.91 \pm 80.7$ & $22.61 \pm 0.9$ \\
\hline Suave & B & nd & $556.16 \pm 97.7$ & $27.55 \pm 4.0$ \\
\hline Suave & $\mathrm{C}$ & nd & $443.14 \pm 74.7$ & $24.85 \pm 5.5$ \\
\hline Native & A & nd & $554.89 \pm 90.5$ & $30.69 \pm 1.0$ \\
\hline Native & B & nd & $604.49 \pm 37.6$ & $31.13 \pm 0.6$ \\
\hline Native & $\mathrm{C}$ & nd & $737.49 \pm 57.7$ & $33.88 \pm 0.6$ \\
\hline
\end{tabular}

nd $=$ not detected

There was no statistical difference among means by Tukey test at 95\% confidence level.

possible to obtain the optimal condition of hydrolysis for the quantification of the caffeic acid and 3,4-dihydroxybenzoic acid, which were initially present in glycosylated forms. The quantification of rutin and of caffeic and 3,4-dihydroxybeonzoic acids before and after acid hydrolysis showed that mate herb has high amounts of these compounds. High levels of rutin were detected before hydrolysis, and after hydrolysis, 3,4-dihydroxybenzoic acid was detected, as well as high levels of caffeic acid. The contents found in the present experiments indicate that the matrix mate herb should be studied as a source of rutin, caffeic acid, and 3,4-dihydroxybenzoic acid.

\section{Acknowledgments}

We would like to thank Ervateira Vier (Santo Cristo, RS, Brazil), by donating the mate herb samples used in this study. This experiment was funded by FAPESP (Fundação de Amparo à Pesquisa do Estado de São Paulo), CAPES (Coordenação de Aperfeiçoamento de Pessoal de Nível Superior), and CNPq (Coordenação Nacional de Desenvolvimento Científico e Tecnológico).

\section{References}

Anvisa (Agência Nacional de Vigilância Sanitária - Brazilian Agency of Sanitary Surveillance) (2012). Available at http://www.anvisa.gov.br/legis/resol/2003/re/899_03re Access in April 25.

Athayde, M. L., Coelho, G. C., \& Schenkel, E. P. (2000). Caffeine and theobromine in epicuticular wax of Ilex paraguariensis A St. Hil. Phytochemistry, 55, 853-8570.

Ballus, C. A., Meinhart, A. D., Bruns, R. E., \& Godoy, H. T. (2011). Use of multivariate statistical techniques to optimize the simultaneous separation of 13 phenolic compounds from extra-virgin olive oil by capillary electrophoresis. Talanta, 83, 1181-1187.

Ballus, C. A., Meinhart, A. D., Oliveira, R. G., \& Godoy, H. T. (2012). Optimization of capillary zone electrophoresis separation and on-line preconcentration of 16 phenolic compounds from wines produced in South America. Food Research International, 45, 136-144.

Bastos, D. H. M., Fornari, A. C., Queiroz, Y. S., \& Torres, E. A. F. S. (2006). Bioactive compounds content of chimarrão infusions related to the moisture of Yerba Maté (Ilex paraguariensis) leaves. Brazilian Archives of Biology and Technology, 49, 399-404.

Berté, K. A. S., Beux, M. R., Spada, P. K. W. D. S., Salvador, M., \& Hoffmann-Ribani, R. (2011). Chemical composition and antioxidant activity of yerba-mate (Ilex paraguariensis A St-Hil, Aquifoliaceae) extract as obtained by spray drying. Journal of Agricultural and Food Chemistry, 59, 5523-5527.

Bixby, M., Spieler, L., Menini, T., \& Gugliucci, A. (2005). Ilex paraguariensis extracts are potent inhibitors of nitrosative stress: A comparative study with green tea and wines using a protein nitration model and mammalian cell cytotoxicity. Life Sciences, 77, 345-358.

Borré, G. L., Kaiser, S., Pavei, C., Silva, F. A., Bassani, V. L., \& Ortega, G. G. (2010). Comparison of methylxanthine, phenolics and saponin contents in leaves, branches and unripe fruits from Ilex paraguariensis A. St.-Hil (Mate). Journal of Liquid Chromatography and Related Technologies, 33, 362-374.

Bravo, L., Goya, L., \& Lecumberri, E. (2007). LC/MS characterization of phenolic constituents of mate (Ilex paraguariensis, St. Hil.) and its antioxidant activity compared to commonly consumed beverages. Food Research International, 40, 393-405.

Buchner, N., Krumbein, A., Rohn, S., \& Kroh, L. W. (2006). Effect of thermal processing on the flavonols rutin and quercetin. Rapid Communications in Mass Spectrometry, 20, 3229-3235.

Cardozo, E. L., Jr., Ferrarese-Filho, O., Cardozo Filho, L., Ferrarese, M. L. L., Donaduzzi, C.M., \& Sturion, J. A. (2007). Methylxanthines and phenolic compounds in mate (Ilex paraguariensis St. Hil.) progenies grown in Brazil. Journal of Food Composition and Analysis, 20, 553-558

Carini, M., Facino, R. M., Aldini, G., \& Colombo, L. (1998). Characterization of phenolic antioxidants from mate (Ilex paraguariensis) by liquid chromatography/mass spectrometry and liquid chromatography/tandem mass spectrometry. Rapid Communications in Mass Spectrometry, 2, 1813-1819.

Clifford, M. N. (1999). Chlorogenic acids and other cinnamates - Nature, occurrence and dietary burden. Journal of the Science of Food and Agriculture, 79, 362-372.

Dartora, N., De Souza, L. M., Santana-Filho, A. P., Iacomini, M., Valduga, A. T., Gorin, P. A. J., et al. (2011). UPLC-PDA-MS evaluation of bioactive compounds from leaves of Ilex paraguariensis with different growth conditions, treatments and ageing. Food Chemistry, 129, 1453-1461.

De Morais, E. C., Stefanuto, A., Klein, G. A., Boaventura, B. C. B., Andrade, F., Wazlawik, E., et al. (2009). Consumption of yerba mate (Ilex paraguariensis) improves serum lipid parameters in healthy dyslipidemic subjects and provides an additional LDL cholesterol reduction in individuals on statin therapy. Journal of Agricultural and Food Chemistry, 57, 8316-8324.

Dutra, F. L. G., Hoffmann-Ribani, R., \& Ribani, M. (2010). Determinação de Compostos Fenólicos por Cromatografia Líquida de Alta Eficiência Isocrática Durante Estacionamento da Erva-Mate. Quimica Nova, 33, 119-123.

Filip, R., Lopez, P., Giberti, G., Coussio, J., \& Ferraro, G. (2001). Phenolic compounds in seven South American Ilex species. Fitoterapia, 72, 774-778.

Filip, R., Lotito, S. B., Ferraro, G., \& Fraga, C. G. (2000). Antioxidant activity of Ilex paraguariensis and related species. Nutrition Research, 20, 1437-1446.

Fuhrman, B., \& Aviram, M. (2002). Polyphenols and flavonoids protect LDL against atherogenic modifications. Handbook of antioxidants (2nd ed.). London: Taylor \& Francis Group.

Gugliucci, A., \& Menini, T. (2002). The botanical extracts of Achyrocline sauteroides and Ilex paraguariensis prevent methylglyoxal-induced inhibition of plasminogen and antithrombin III. Life Sciences, 72, 279-292.

Heck, C. I., \& Mejia, E. G. (2007). Yerba mate tea (Ilex paraguariensis): A comprehensive review on chemistry, health implications, and technological considerations. Journal of Food Science, 72, 138-151.

Heller, M., Vitali, L., Oliveira, M. A. L., Costa, A. C. O., \& Micke, G. A. (2011). A rapid sample screening method for authenticity control of whiskey using capillary electrophoresis with online preconcentration. Journal of Agricultural and Food Chemistry, 59, 6882-6888.

Honegr, J., Šafra, J., Polašek, M., \& Pospíšilová, M. (2010). Large-volume sample stacking with polarity switching in $\mathrm{CE}$ for determination of natural polyphenols in plant extracts. Chromatographia, 72, 885-891.

Huber, L. S., Hoffmann-Ribani, R., \& Rodriguez-Amaya, D. B. (2009). Quantitative variation in Brazilian vegetable sources of flavonols and flavonas. Food Chemistry, $113,1278-1282$

Ibge (Instituto Brasileiro de Geografia e Estatística - Brazilian Geography and Statistics Institute) (2012). Available at http://www.ibge.gov.br/home/estatistica/populacao/ condicaodevida/pof/2008_2009_analise_consumo/pofanalise_2008_2009.pdf Access in April 25.

Kussler, A. L., Sabedot, S. M., Garcia, F. R. M., \& Peronti, A. L. B. G. (2004). Primeiro registro da cochonilha Pendularia paraguariensis Granara de Willink, 1999 (Hemiptera: Coccidae) no Brasil. Ciência Rural, 34, 1231-1233.

Lee, I. S. L., Boyce, M. C., \& Breadmore, M. C. A. (2011). A rapid quantitative determination of phenolic acids in Brassica oleracea by capillary zone electrophoresis. Food Chemistry, 127, 797-801.

Meinhart, A. D., Ballus, C. A., Bruns, R. E., Lima Pallone, J. A., \& Godoy, H. T. (2011). Chemometrics optimization of carbohydrate separations in six food matrices by micellar electrokinetic chromatography with anionic surfactant. Talanta, 85, 237-244.

Meinhart, A. D., Bizzotto, C. S., Ballus, C. A., Prado, M. A., Bruns, R. E., Teixeira-Filho, J., et al. (2010). Optimisation of a CE method for caffeine analysis in decaffeinated coffee. Food Chemistry, 120, 1155-1161.

Meinhart, A. D. Bizzotto, C. S., Ballus, C. A., Rybka, A. C. P. Sobrinho, M. R., Cerro-Quintana, R. S., et al. (2010). Methylxanthines and phenolics content extracted during the consumption of mate (Ilex paraguariensis St. Hil) beverages. Journal of Agricultural and Food Chemistry, 58, 2188-2193.

Mosimann, A. L. P., Wilhelm-Filho, D. \& Silva, E. L. (2006). Aqueous extract of Ilex paraguariensis attenuates the progression of atherosclerosis in cholesterol fed rabbits. Biofactors, 26, 59-70.

Murakami, A. N. N., Amboni, R. D. M. C., Prudêncio, E. S., Amante, E. R., Zanotta, L. M., Maraschin, M., et al. (2011). Concentration of phenolic compounds in aqueous 
mate (Ilex paraguariensis A. St. Hil) extract through nanofiltration. LWT-Food Science and Technology, 44, 2211-2216.

Pagliosa, C. M., Vieira, M. A., Podestá, R., Maraschin, M., Zeni, A. L. B., Amante, E. R., et al. (2010). Methylxanthines, phenolic composition, and antioxidant activity of bark from residues from mate tree harvesting (Ilex paraguariensis A. St. Hil.). Food Chemistry, 122, 173-178.

Pomilio, A. B., Trajtemberg, S., \& Vitale, A. A. (2001). High-performance capillary electrophoresis analysis of Mate infusions prepared from stems and leaves of Ilex paraguariensis using automated micellar electrokinetic capillary chromatography. Phytochemical Analysis, 13, 235-241.

Rivelli, D. P., Almeida, R. L., Ropke, C. D., \& Barros, S. B. M. (2011). Hydrolysis influence on phytochemical composition, antioxidant activity, plasma concentration, and tissue distribution of hydroethanolic Ilex paraguariensis extract components. Journal of Agricultural and Food Chemistry, 59, 8901-8907.
Scalbert, A., Manach, C., Morand, C., Rémésy, C., \& Jiménez, L. (2005). Dietary polyphenols and the prevention of diseases. Critical Reviews in Food Science and Nutrition, 45, 287-306.

Scherer, R., \& Godoy, H. T. (2009). Antioxidant activity index (AAI) by the 2,2-diphenyl-1-picrylhydrazyl method. Food Chemistry, 112, 654-658.

Vieira, M. A., Rovaris, A. A., Maraschin, M., Simas, K. N., Pagliosa, C. M., \& Podestá, R. (2008). Chemical characterization of candy made of erva-mate (Ilex paraguariensis A. St. Hil.) residue. Journal of Agricultural and Food Chemistry, 56, 4637-4642.

Zuin, V. G., Montero, L., Bauer, C., \& Popp, P. (2005). Stir bar sorptive extraction and high performance liquid chromatography-fluorescence detection for the determination of polycyclic aromatic hydrocarbons in Mate teas. Journal of Chromatography. A, 1091, 2-10. 